\title{
Comment on "Prevalence of dyspeptic symptoms and heartburn of adults in Belo Horizonte, Brazil"
}

\author{
Katherine Maria USNAYO, Pierre PALACIOS and Alejandro PISCOYA
}

Received 18/4/2017 Accepted 19/4/2017

Usnayo KM, Palacios P, Piscoya A. About "Prevalence of dyspeptic symptoms and heartburn of adults in Belo Horizonte, Brazil". Arq Gastroenterol. 2017;54(3):267.

HEADINGS - Dyspepsia, diagnosis. Heartburn. Consenso.

\section{To the editor}

We have read with interest the article entitled: "Prevalence of dyspeptic symptoms and heartburn of adults in Belo Horizonte, Brazil'"(1). We would like to emphasize the importance of this article due to the little number of articles written in Latin America compared to those existing in other parts of the world.

The systematic review on global prevalence of dyspepsia by Ford et al. 2014, shows a prevalence of 15\%-19.9\% for Brazil, which is not consistent with the results of Almeida et al. This study also shows a 35\% higher prevalence in Perú, and 37.7\% for South America. Both are very high numbers and are maybe because the population of the studies considered are quite specific and not represent the general population ${ }^{(2)}$.
On the other hand, in a Peruvian research conducted in medical students in 2015, the prevalence of dyspepsia was $16.3 \%$, which results are much closer to the $10.6 \%$ found in the study made in Brazil ${ }^{(4)}$. Also, it was found that alcohol intake is related to dyspepsia, which is consistent with the findings in the article made by Almeida et al. ${ }^{(1)}$.

We consider that it is necessary to describe other risk factors for the development of dyspepsia, such as: NSAIDs consumption and Helicobacter pylori infection; since both are also important for the development of this pathology $y^{(3)}$, so we believe that it would be necessary to perform a Latin American study in collaboration with all the countries of the region to obtain accurate data of this important and prevalent pathology.

Usnayo KM, Palacios P, Piscoya A. Comentário sobre "Prevalência de sintomas dispépticos e de pirose em uma população de adultos em Belo Horizonte, Brasil”. Arq Gastroenterol. 2017;54(3):267.

DESCRITORES - Dispepsia, diagnóstico. Azia. Consensus.

\section{REFERENCES}

1. Almeida AM, Martins LA, Cunha PL, Brasil VW, Félix LG, Passos MD. Prevalence of dyspeptic symptoms and heartburn of adults in Belo Horizonte, Brazil. Arq Gastroenterol. 2017;54:46-50.

2. Ford AC, Marwaha A, Sood R, Moayyedi P. Global prevalence of, and risk factors for, uninvestigated dyspepsia: a meta-analysis. Gut. 2015;64: 1049-57.
3. Mahadeva S, Goh KL. Epidemiology of functional dyspepsia: a global perspective. World J Gastroenterol. 2006;12:2661-6.

4. Vargas-Matos I, Ng-Sueng LF, Flores-Arriaga J, Beltrán-Flores S, Lema-Correa M, Piscoya A, Mayta-Tristán P. Overlap of irritable bowel syndrome and functional dyspepsia based on Rome III criteria in medical students from a private university in Lima, Peru. Rev Gastroenterol Perú. 2015;35:129-225. 